\title{
Saneamiento en territorios indígenas de Nicaragua: Un proceso en construcción dentro de la Autonomía Regional
}

\section{Gema Lorio}

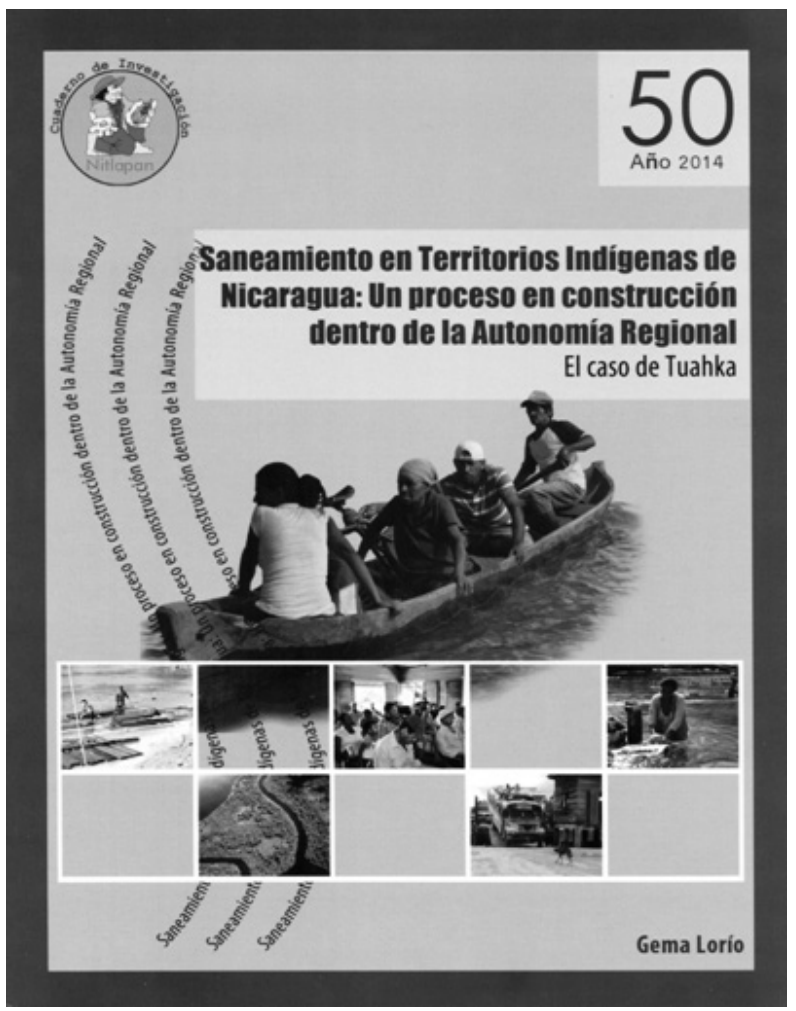

La Investigación aborda la situación de la gobernanza de los recursos naturales, y los procesos de demarcación y titulación en América Latina y Nicaragua. Particularmente hace énfasis en los resultados de un estudio de caso aplicado en un territorio Mayagna (Tuahka) de la Costa Caribe nicaragüense. En éste se presenta el proceso y estrategia que ha seguido el gobierno territorial en relación a la demarcación y titulación de la propiedad.

El cuaderno No. 50 puede descargarse libremente del sitio Web del Instituto Nitlapan de la Universidad Centroamericana: http://www. nitlapan.org.ni/ 